\title{
AN INTERNATIONAL STUDY OF MENTAL HEALTH DIFFICULTIES AMONG FAMILIES AFFECTED BY HUNTINGTON'S DISEASE
}

\author{
Dr Maria Dale, Dawn Freire-Patino, Noora Ovaska-Stafford \& Prof John Maltby
}

\section{Objective:}

To characterize mental health difficulties across families affected by Huntington's disease among an international cohort.

\section{Background:}

Mental health difficulties are a core feature of Huntington's disease, an incurable genetic neurodegenerative disorder. Despite the familial nature of this condition, very few studies have examined mental health difficulties in both Huntington's disease gene carriers and family members who do not have the gene.

\section{Materials and methods:}

Data were obtained from Enroll-HD a multinational, observational study of HD. Our data included mental health assessments using the Problem Behavior Assessment (short form) for Huntington's disease available from the project up to 2018. Our total sample included 5294 participants (Europe, $n=2643$; US, $n=$ 2339; Australasia, $n=275$; Latin America, $n=37$ ). Of this sample 2509 respondents were motorsymptomatic, 1226 respondents were pre-motor symptomatic, 808 participants were genotype negative and 751 participants were family controls. Descriptive statistics were used to examine prevalence across a range of mental health issues for the 4 groups.
Table 1: illustrating prevalence of mental health issues across Huntington disease family members using the PBA-s for Huntington's disease (score $\geq 2$ )

\begin{tabular}{|r|r|r|r|r|}
\hline & $\begin{array}{r}\text { Motor- } \\
\text { symptomatic } \\
(\mathrm{n}=2509)\end{array}$ & $\begin{array}{r}\text { Pre-motor- } \\
\text { symptomatic } \\
(\mathrm{n}=1226)\end{array}$ & $\begin{array}{r}\text { Genotype } \\
\text { negative } \\
(\mathrm{n}=808)\end{array}$ & $\begin{array}{r}\text { Family } \\
\text { Controls } \\
(\mathrm{n}=751)\end{array}$ \\
\hline PBA-S items & & & & \\
\hline Depression & $44.7 \%$ & $37.8 \%$ & $21.9 \%$ & $30.8 \%$ \\
\hline $\begin{array}{r}\text { Suicide } \\
\text { ideation }\end{array}$ & $6.0 \%$ & $4.8 \%$ & $1.7 \%$ & $1.3 \%$ \\
\hline Anxiety & $45.7 \%$ & $42.2 \%$ & $31.9 \%$ & $36.9 \%$ \\
\hline Irritability & $41.5 \%$ & $31.1 \%$ & $17.6 \%$ & $24.5 \%$ \\
\hline Aggression & $22.2 \%$ & $12.6 \%$ & $7.2 \%$ & $8.8 \%$ \\
\hline Apathy & $47.7 \%$ & $19.2 \%$ & $9.2 \%$ & $9.2 \%$ \\
\hline Ob-Comp & $32.9 \%$ & $13.3 \%$ & $6.8 \%$ & $7.5 \%$ \\
\hline Perseveration & $19.2 \%$ & $9.2 \%$ & $6.7 \%$ & $3.6 \%$ \\
\hline Paranoid & $4.4 \%$ & $1.4 \%$ & $1.0 \%$ & $0.4 \%$ \\
\hline Thinking & & & & $0.4 \%$ \\
\hline Hallucinations & $1.1 \%$ & $0.6 \%$ & $0.6 \%$ & \\
\hline Disorientation & $15.3 \%$ & $2.0 \%$ & $1.0 \%$ & $0.4 \%$ \\
\hline & & & & \\
\hline
\end{tabular}

\section{Results:}

Among those with a clinical diagnosis of Huntington's disease, apathy was the most prevalent mental health issue, affecting $47.7 \%$ of the sample. This was followed by anxiety (45.7\%), depression (44.7\%) and irritability (41.5\%). Anxiety was the most common issue among gene carriers who had not yet developed motor signs $(42.2 \%)$ and for family members without the gene.

tive

Bar chart demonstrating prevalence of mental health issues across Huntington disease family members using the PBA-s (score $\geq 2$ )

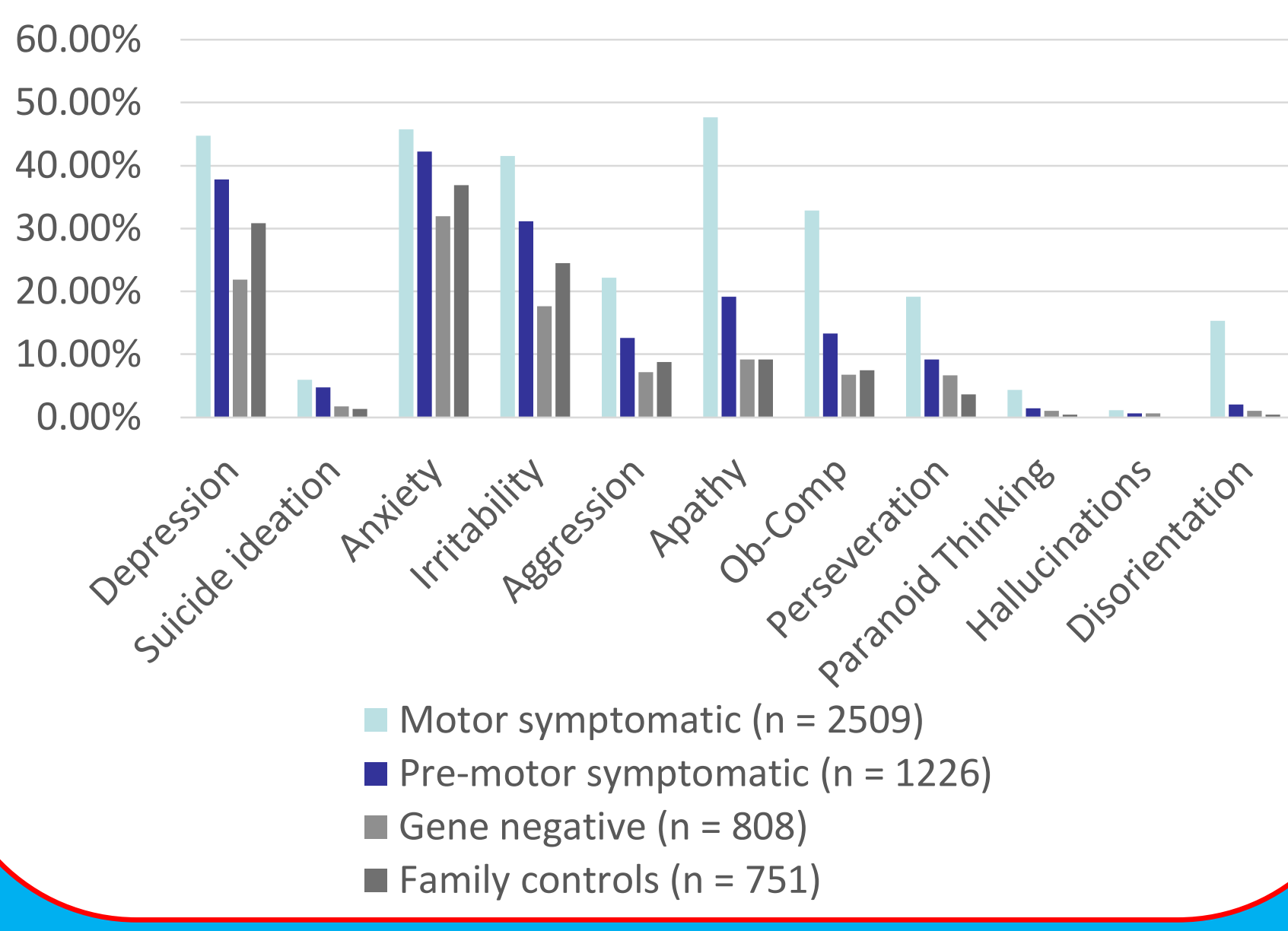

\section{Conclusions:}

Apathy is a key feature of mental health difficulties among HD patients, but those pre-motor symptomatic and family controls more commonly experience anxiety and depression.

Acknowledgements: Enroll-HD is a clinical research platform and longitudinal observational study for Huntington's disease families intended to accelerate progress towards therapeutics; it is sponsored by CHDI Foundation, a nonprofit biomedical research organization exclusively dedicated to collaboratively developing therapeutics for HD. Enroll-HD would not be possible without the vital contribution of the research participants and their families.

This work was funded by the National Institute for Health Research CLAHRC East Midlands UK. 